\title{
POLYCYCLIC AROMATIC HYDROCARBON, HAEMATOLOGICAL AND OXIDATIVE STRESS LEVELS IN COMMERCIAL PHOTOCOPIER OPERATORS IN LAGOS, NIGERIA
}

\author{
O. AWODELE, A.J. AKINDELE, G.O. ADEBOWALE and O.O. ADEYEMI \\ Department of Pharmacology, Therapeutics \& Toxicology, College of Medicine, University of Lagos, Idi- \\ Araba Campus, PMB 12003, Lagos, Nigeria
}

DOI: http://dx.doi.org/10.4314/gmj.v49i1.7

Corresponding Author: Prof. Olaide Olufunmilayo Adeyemi

Conflict of Interest: None declared

\section{SUMMARY}

Background: Human exposure to hazardous substances in the environment has been known to play an important role in the pathogenesis of some diseases. Photocopying machines have become a cheap source of self-employment in Nigeria. For obvious reasons the highest level of patronage is encountered in the campuses of educational institutions. However, the persons who operate the machines are always exposed to possible hazards associated with the job without protective devices.

Objective: This study investigated the levels of oxidative stress, polycyclic aromatic hydrocarbon (PAH) and haematological parameters in blood samples of photocopier operators.

Methods: The experimental procedure involved 50 consented subjects selected based on some criteria. The haematological parameters, oxidative stress and PAH levels were determined using standard methods.

Results: The results showed no significant difference $(p \geq 0.05)$ in the haematological parameters between the test subjects and the controls. However, there were duration on the job (yrs) dependent significant decrease in the level of superoxide dismutase (SOD) of the photocopier operators compared with the controls ( $>5$ years $\mathrm{p} \leq 0.0001 ; 4-5$ years $\mathrm{p} \leq 0.001)$. The level of reduced glutathione (GSH) was significantly decreased across all lengths of duration on the job compared with the controls.

Conclusion: The findings in this study revealed increased level of oxidative stress in photocopier operators with no significant change in haematological parameters. The health implication of operating photocopiers call for quick health education and intervention tailored to monitoring and guiding the photocopier operators. This will help to prevent or manage continuous exposure to the hazards of photocopying machines.
Email:ooadey@yahoo.com

Keywords: Photocopier operators, oxidative stress, $\mathrm{PAH}$, haematology, Nigeria.

\section{INTRODUCTION}

Exposure of humans to hazardous substances in the environment has been known to play an important role in the pathogenesis of some diseases. ${ }^{1}$ Exposure to toxic substances at work places like in shoe-making companies, tobacco and rubber industries and to petrochemicals can pose a serious health hazard. ${ }^{2-5}$ In addition, workers may also be exposed to additional toxic substances due to their social habits such as smoking, tobacco chewing and alcohol consumption.

As a result of massive unemployment and economic downturn, photocopying machines have become a cheap source of self-employment in Nigeria and for obvious reason the highest level of patronage is encountered in educational institutions. ${ }^{6}$ Most of the photocopy shops/centres in Nigerian universities exhaust one thousand sheets of paper daily for photocopying activities and minimum of 349,000 sheets of duplicating paper per day goes for photocopying in eight selected universities in South West Nigeria. ${ }^{6}$

The report of Gadhia et $a l^{7}$ has also shown that photocopiers are used in many work places as a good source of employment and are common machines in Indian markets. The persons who operate the machines are always exposed to possible hazards associated with it. Toner which is the main component of the photocopying machine consists of carbon black (17\%), polycyclic aromatic hydrocarbons $(\mathrm{PAH})^{8}$, styrene, magnetite, nitropyrenes, benzene, toluene, other volatile substances and low melt polymer resins mixed with minute steel, silica or ferrite bead. ${ }^{9}$ 
The operators are exposed to toner (while reloading and unloading the machines) and to toxic gases like ozone, nitrogen dioxide, volatile organic compounds and extremely low frequency electromagnetic fields during their operation ${ }^{8-12}$. Majority of these agents have been reported to be mutagenic or genotoxic in either bacterial or mammalian systems. 9;13-15

Experimental procedure using comet assay measurement showed that workers occupationally exposed to photocopying machines suffer increased basal DNA damage. ${ }^{16-17}$ However, significant association was found between years of exposure, smoking, age, gender, alcohol consumption and high level of DNA damage. ${ }^{17}$ Reduced level of anti-oxidants like vitamin $\mathrm{C}$ and $\mathrm{E}$ and superoxide dismustase (SOD) and high activity of lipid peroxidation were detected in the blood samples of photocopier operators. ${ }^{5}$ The earlier study of Zhou et al. ${ }^{5}$ suggested that ozone, which is one of the gasses released from photocopier toner, causes oxidative damage in copier operators.

Occupational autoimmune disease in photocopying machine workers has also been reported. ${ }^{18}$ Haematological study of total red blood cells, total white blood cells, haemoglobin percentage and platelet count from photocopying machine operators did not reveal any untoward variations from normal values and measurement of their blood pressure showed normal pattern. $^{7}$

The aim of the present study is to determine the level of oxidative stress markers in the blood of workers occupationally exposed to photocopying machines, evaluate the effect on blood cells, and assess the types and levels of polycyclic aromatic hydrocarbon (PAH) in their plasma. To the best of our knowledge, similar or related studies in this category have not been carried out among Nigerian photocopier operators. It is hoped that the findings will lead to appropriate recommendations that will reduce the long term health implications of operating photocopying machines.

\section{METHODS}

\section{Study Area}

The two main study areas are the University of Lagos Main Campus, Akoka and the University of Lagos, College of Medicine, Idi-Araba, Lagos, Nigeria. University of Lagos is located in South West Nigeria bordered by the panoramic Lagos lagoon. The total students' population is about fifteen thousand with an estimated two hundred and seventy commercial photocopier operators working in both campuses of the University.

\section{Study Population}

The experimental procedure involved 50 consented subjects. The selection criteria of the study subjects were based on the outcome of the preliminary survey carried out. The photocopier operators voluntarily signed an informed consent form at the beginning of the survey and the consented operators responded to an elaborate questionnaire to determine their sociodemographical data and some job related issues. One hundred and twenty-six questionnaires were returned out of the two hundred and sixty-one that were distributed. Some categories of respondents were excluded from the experimental procedure due to their work experience in factories that are noted for harmful emissions similar to those of photocopiers, females for physiological reasons, smokers and alcoholics because of their increased oxidative stress tendency. Also the subjects selected did not include those that had been taking any anti-oxidant on a regular basis or had been exposed to any kind of radiation for 12 months before the exercise.

\section{EXPERIMENTAL PROCEDURE Study Group}

The fifty selected subjects were divided into five categories. The first four categories consist of 10 subjects each of photocopier operators. The duration of the subjects on this job formed the basis of their grouping into different categories (2-3 yrs, 3-4 yrs, 4-5 yrs and $>5$ yrs). The control subjects also consist of 10 consented students of the University who were neither smokers nor alcoholics.

\section{Sample Collection}

Blood samples were collected by skilled hands under sterile conditions through venipuncture. About $3 \mathrm{mls}$ of blood were transferred into sodium heparinised bottles for centrifugation and the plasma obtained stored at $30{ }^{\circ} \mathrm{C}$ for antioxidants and lipid peroxidation assays. Another $2 \mathrm{mls}$ were transferred into EDTA bottles for haematological analysis. While $1 \mathrm{ml}$ of the blood samples was withdrawn into the plain bottles for polycyclic aromatic hydrocarbon (PAH) assay.

\section{Measurement of Haematological Parameters, Antioxidant Enzymes and Lipid Peroxidation}

The haematological parameters (White blood cells, Haemoglobin, Neutrophils, Monocytes, Eosinophils and Lymphocytes) were analysed using fully automated clinical haematological analyzer (Hitachi 912, Boehringer Mannheim, Germany). Measurements of antioxidant enzymes activity and lipid peroxidation were done according to standard procedures: catalase $^{19,21}$; superoxide dismutase $(\mathrm{SOD})^{21}$; malondialdehyde $(\mathrm{MDA})^{21-22}$; reduced glutathione 
(GSH) and glutathione-S-transferase (GST) were determined using the methods of Beers and Seizer ${ }^{19}$ and Beuge and Aust. ${ }^{20}$

\section{Determination of Polycyclic Aromatic Hydro- carbons \\ Reagents}

The liquid chromatography-grade dichloromethane used for extractions was obtained from Lord Abis Nigeria Ltd. The silica gel used to clean up the extracts was supplied by BDH Enterprises. PAH standard mixture (Agilent Technologies, USA) containing naphthalene, acenaphthylene, acenaphthene, fluorine, phenatrene, anthracene, fluoranthene, pyrene, benz(a)pyrene, chrysene, benzo(ghi)perylene, dibenz(a,h)anthracene and indeno(1,2,3-cd) pyrene was used in this study.

\section{GC Analysis}

The standard procedure was used to extract the polycyclic aromatic hydrocarbons from the biological sample. The 7890A, MS5975C models of GC-MS system and 7683B with 8 auto-samplers injector supplied by Agilent Technologies (USA) were used for GC analysis. The column used was HP-5 MS with a length of 30 metres, internal diameter of $0.32 \mathrm{~mm}$ and film of $0.25 \mu \mathrm{m}$ fused silica capillary column and helium as the carrier gas. The pressure flow was 10 psi to give approximate flow rate of $1 \mathrm{ml} / \mathrm{min}$.

The injector and transferred line were maintained at $290^{\circ} \mathrm{C}$ and $250^{\circ} \mathrm{C}$ respectively. All injection volumes were $1 \mu 1$ in a split mode. The column initial temperature was held at $100^{\circ} \mathrm{C}$ for 4 mins rampled to $300^{\circ} \mathrm{C}$ at a rate of $8^{\circ} \mathrm{C} / \mathrm{min}$, and held at $300^{\circ} \mathrm{C}$ for 10 mins. The mass spectrometer was used in electron ionization mode and all spectra were acquired using a mass range of $50-400 \mathrm{~m} / \mathrm{z}$ and an automatic gain control.

\section{Determination of Air Emission/Concentration}

The determination of air emission/concentration at photocopier operation site was carried out by using Testo 350 emission analyzer. This instrument was obtained from the Lagos State Environmental Protection Agency, Ikeja, Lagos, Nigeria. The emission testing relies on proper hardware coupled with accurate measurements. The sensors were integrated, flow rate controlled and exhaust gas conditioned for appropriate detection of air emission gases. The operation was carried out by clicking the application icon and the air emission analyzer automatically began processing the levels of air emission gasses at the site of operation.

\section{Statistical analysis}

The socio-demographical data were presented in frequency distribution tables with percentages and experimental results were presented as mean \pm S.E.M. Statistical significance between the control group and the test groups were analyzed by means of Student's ttest. $P$ values less than 0.05 were considered significant.

\section{RESULTS}

Table 1 results show the socio-demographic data of the photocopier operators. The highest age distribution $(60.30 \%)$ of the subjects was found to be between 15 25 years and the lowest $(1.6 \%)$ was found to be between $46-55$ years.

Table 1 Socio-demographic data of photocopier operators

\begin{tabular}{|c|c|c|}
\hline Age & Frequency & $\%$ \\
\hline 15-25years & 76 & 60.3 \\
\hline 26-35years & 36 & 28.6 \\
\hline 36-45years & 12 & 9.5 \\
\hline 46-55years & 2 & 1.6 \\
\hline \multicolumn{3}{|c|}{ Gender } \\
\hline Male & 77 & 61.1 \\
\hline Female & 49 & 38.9 \\
\hline \multicolumn{3}{|c|}{ Level of education } \\
\hline No formal education & 7 & 5.5 \\
\hline Primary & 14 & 11.1 \\
\hline Secondary & 85 & 67.5 \\
\hline Tertiary & 18 & 14.3 \\
\hline Post-graduate & 2 & 1.6 \\
\hline \multicolumn{3}{|c|}{ Duration of employment } \\
\hline$<1$ year & 40 & 31.7 \\
\hline$>1-2$ years & 18 & 14.3 \\
\hline$>2-3$ years & 15 & 11.9 \\
\hline$>3-4$ years & 13 & 10.3 \\
\hline$>4-5$ years & 14 & 11.1 \\
\hline$>5$ years & 26 & 20.6 \\
\hline
\end{tabular}

There were more male subjects $(61.10 \%)$ than female and most of them had secondary education $(67.50 \%)$. The results further showed that $31.70 \%$ of the subjects had spent less than 1 year on the job as photocopier operators while $20.60 \%$ had spent more than 5 years on the job. Slightly larger proportions of the subjects $(52.40 \%)$ like their job as photocopier operators (Table 2). 
Table 2 Job related information about the photocopier operators

\begin{tabular}{|l|ll|lc|}
\hline & YES & \% & NO & \% \\
\hline Like the job? & 60 & 47.6 & 66 & 52.4 \\
\hline $\begin{array}{l}\text { Has worked in cement factory, } \\
\text { petrochemical or other related } \\
\text { hazardous companies }\end{array}$ & 30 & 23.8 & 96 & 76.2 \\
\hline Smokes & 24 & 19.0 & 102 & 81.2 \\
\hline Aware of hazards of photocopiers & 58 & 46.0 & 68 & 54.0 \\
\hline Takes precautionary measures & 42 & 33.3 & 84 & 66.7 \\
\hline Operates in a crowded office/shop & 109 & 86.5 & 17 & 13.5 \\
\hline
\end{tabular}

Total number of respondents $126(100 \%)$

Majority of the subjects had not worked in any hazardous companies previously $(76.20 \%)$ and were not known smokers $(81.00 \%)$. Although, most of the subjects were aware of the hazards of photocopiers $(54.00 \%)$, very few proportions $(33.30 \%)$ took precautionary measures during their operation of photocopying machine. The results also showed that most of the photocopier operators worked in a crowded office/shop (86.50\%).

Table 3 Haematological parameters of photocopier operators

\begin{tabular}{|c|l|l|l|l|c|}
\hline & $\mathbf{H b} / \mathbf{g}$ & $\mathbf{W B C} / \mathbf{c m} 3$ & \% Neut & \% Lym & \% Mono \\
\hline Control & $14.2 \pm 0.3$ & $5010.0 \pm 405.1$ & $55.8 \pm 1.4$ & $34.5 \pm 1.0$ & $6.4 \pm 0.5$ \\
\hline $2-3 \mathrm{yr}$ & $13.8 \pm 0.4$ & $4220.0 \pm 515.1$ & $57.3 \pm 0.7$ & $32.6 \pm 0.7$ & $5.6 \pm 0.3$ \\
\hline $3-4 \mathrm{yr}$ & $13.5 \pm 0.2$ & $5780.0 \pm 300.3$ & $57.1 \pm 1.2$ & $32.5 \pm 0.6$ & $5.4 \pm 0.4$ \\
\hline $4-5 \mathrm{yr}$ & $13.1 \pm 0.4$ & $5110.0 \pm 500.3$ & $56.8 \pm 0.8$ & $33.5 \pm 0.8$ & $6.1 \pm 0.3$ \\
\hline$>5 \mathrm{yr}$ & $14.7 \pm 0.2$ & $5550.0 \pm 482.9$ & $58.7 \pm 0.7$ & $33.4 \pm 0.4$ & $6.4 \pm 0.5$ \\
\hline
\end{tabular}

There were duration on the job (yrs) dependent significant decrease $(>5$ yrs $p \leq 0.0001 ; 4-5$ yrs $p \leq$ 0.001 ) in the level of SOD of the photocopier operators compared with the control (Table 4).

Table 4 Oxidative stress parameters of photocopier operators

\begin{tabular}{|l|c|c|c|c|}
\hline & SOD $(\mathrm{U} / \mathrm{mg})$ & $\begin{array}{c}\text { GSH } \\
(\mathrm{nm} / \mathrm{mg})\end{array}$ & CAT (U/mg) & MDA (nm/mg) \\
\hline Control & $129.3 \pm 7.37$ & $1.85 \pm 0.13$ & $595.0 \pm 30.43$ & $0.024 \pm 0.004$ \\
\hline 2-3yrs & $114.9 \pm 4.76$ & $1.12 \pm 0.20^{*}$ & $515.7 \pm 27.04$ & $0.217 \pm 0.082$ \\
\hline 3-4yrs & $129.1 \pm 10.46$ & $1.09 \pm 0.15^{*}$ & $448.5 \pm 70.84$ & $0.306 \pm 0.039^{*}$ \\
\hline 4-5yrs & $68.8 \pm 8.45^{\wedge}$ & $0.97 \pm 0.15^{*}$ & $378.2 \pm 73.84$ & $0.386 \pm 0.071^{* *}$ \\
\hline$>5 \mathrm{yrs}$ & $61.3 \pm 9.15^{\wedge}$ & $1.11 \pm 0.22^{*}$ & $348.8 \pm 78.96^{*}$ & $0.672 \pm 0.119^{\wedge}$ \\
\hline \multicolumn{5}{|c|}{$\mathrm{p}<0.05^{*} ; \mathrm{p}<0.001^{* *} ; \mathrm{p}<0.0001^{\wedge}$}
\end{tabular}

The level of GSH significantly ( $\mathrm{p} \leq 0.05)$ decreased across all length of duration on the job (years) compared with the control. However, only the subjects who had stayed for more than five years on the job as photocopier operators had significant $(\mathrm{p} \leq 0.05)$ decrease in the level of CAT $(348.80 \pm 78.96 \mathrm{U} / \mathrm{mg})$ compared with the control $(595.00 \pm 30.43 \mathrm{U} / \mathrm{mg})$. There was also duration on the job dependent significant increase $(3-4$ yrs $\mathrm{p} \leq 0.05 ; 4-5$ yrs $\mathrm{p} \leq$ $0.001 ;>5$ yrs $\mathrm{p} \leq 0.0001)$ in the level of lipid peroxidation (MDA) of the photocopier operators compared with the control (Table 4)

The common health problems of the photocopier operators as shown in Figure 1 are eye irritation, headache, dizziness and catarrh. The haematological parameters results (Table 3) showed no significant difference $(p \geq 0.05)$ in the levels of haemoglobin, white blood cells, neutrophils, lymphocytes, monocytes and eosinophils between the photocopier operators and the control subjects.

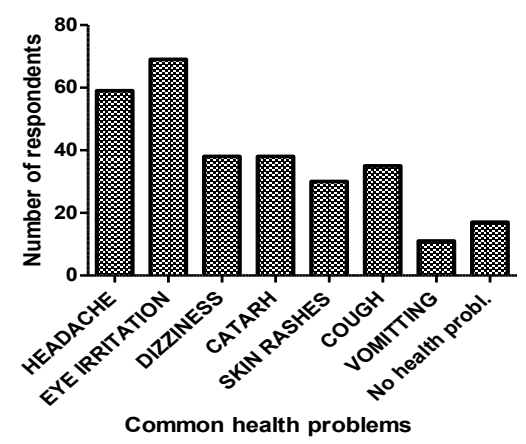

Figure 1 Common health problems of photocopier operators

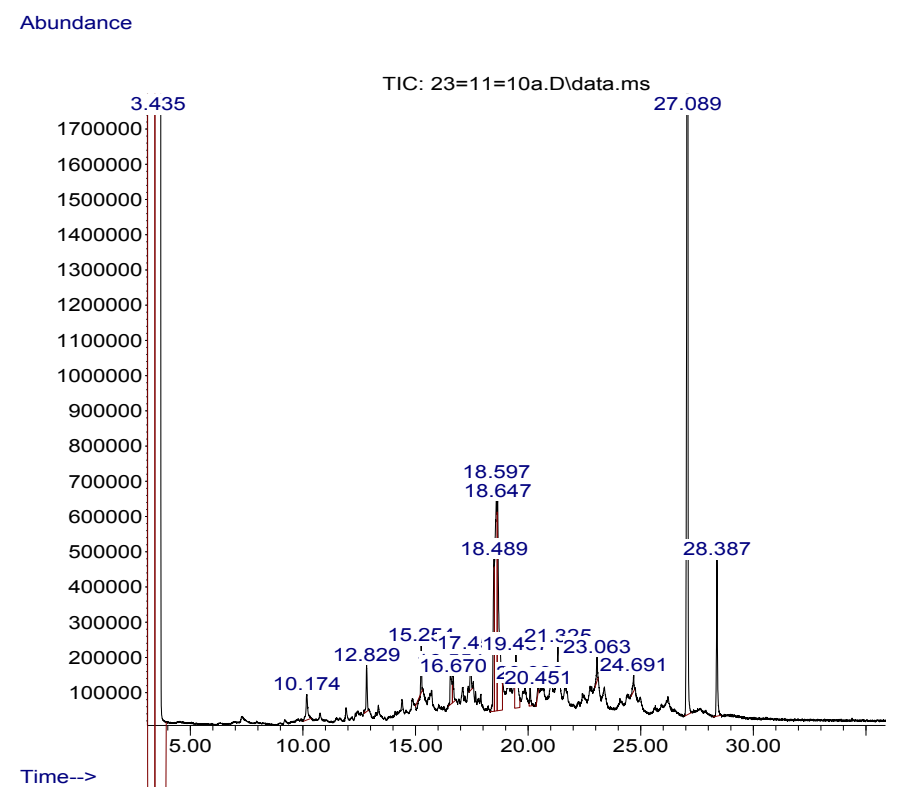

Figure 2 Chromatogram of photocopier operators' plasma for polycyclic aromatic hydrocarbon 
The combination of retention time match and mass spectral match of GC/MS of the plasma of photocopier operators and control subjects did not show any polycyclic aromatic hydrocarbon (Figure 2).

Analysis of the air emission showed no detection of $\mathrm{CO}, \mathrm{NO}_{3}, \mathrm{NO}, \mathrm{NO}_{2}, \mathrm{CO}_{2}, \mathrm{SO}_{2}$, and hydrocarbons at the sites using electric power while the air emission at photocopier operation site using petrol generator showed significant high level of hydrocarbons (152 ppm) in comparison with the environmental protection agency level (0.008 ppm).

\section{DISCUSSION}

Photocopiers have been a good source of job opportunity for most secondary school leavers in Nigeria as it is easy to operate and commercially needed in almost all our tertiary institutions. This same phenomenon occurs in India where photocopiers are good source of employment and most common machines in Indian markets. ${ }^{7}$ The people who operate the machines are exposed to possible hazards associated with it.

'Toner' is the main component of photocopying machine that mainly consist of carbon black (17\%), polycyclic aromatic hydrocarbons (PAHs), styrene, magnetite, nitropyrenes, benzene, toluene, other volatile substances and low melt polymer resins mixed with minute steel, silica or ferrite beads. Besides these, ozone, nitrogen dioxide, volatile organic compounds like 1-1, biphenyl p-dichlorobenzene pyrolbenzene and tetrachloroethylene aldehydes are also released into the atmosphere by the machines while in operation. ${ }^{7}$

It is well known that superoxide dismutase, catalase and reduced glutathione are important endogenous antioxidants in human bodies. They play important roles in scavenging free radicals like superoxides $\left(\mathrm{O}^{\circ}\right)$, hydroxyl group $(\mathrm{OH})$ as well as reactive oxygen species like singlet oxygen $\left({ }^{1} \mathrm{O}_{2}\right)$ and hydrogen peroxides $\left(\mathrm{H}_{2} \mathrm{O}_{2}\right)$ which are excessively generated in human bodies either naturally or upon exposure to environmental or occupational hazardous substances. ${ }^{23-}$ 27 These antioxidants also play important roles in preventing physiological and pathological aggravation of series of free radical chain reactions thereby protecting biological membranes of the cells from oxidative stress and oxidative damage. ${ }^{23 ; 28-33}$

The results obtained from this study had shown that there is a significantly higher level of oxidative stress in workers occupationally exposed to photocopiers compared to the control subjects. This finding agrees with earlier findings of Zhou et al. ${ }^{5}$ who demonstrated that photocopying machine workers suffer an increased level of lipoperoxidase in plasma and red blood cells as well as reduced levels of superoxide dismutase, catalase and glutathione peroxidase. This may be correlated to work load as expressed by the number of machine activations.

This present study revealed duration of occupation dependent decrease in the level of SOD of the photocopier operators compared with the control and also significant increase (3-4 yrs $\mathrm{p} \leq 0.05 ; 4-5$ yrs $\mathrm{p} \leq$ $0.001 ;>5$ yrs $p \leq 0.0001)$ in the level of lipid peroxidation (MDA) of the photocopier operators compared with the control. These observations may be due to the presence of ozone, PAH and ultraviolet emission from the photocopying machines which may induce reactive oxygen species in exposed tissue. This leads to increasing production of highly toxic hydroxyl radicals and increasing chronic oxidative stress in the bodies of the photocopier operators. ${ }^{5}$ The health implications of photocopiers had earlier been shown by Bar-Sela and Shoenfeld ${ }^{18}$; Goud et al. ${ }^{16}$ to include autoimmune disorder and DNA damage. This present study has also shown that eye irritation, headache, dizziness and catarrh were common health complaints of photocopier operators.

However, the haematological parameters of the photocopier operators were normal compared with the control subjects. This finding corroborates the work of Gadhia et $a l^{7}$ that showed Indian photocopier operators to have normal haematological parameters and blood pressure values.

The non-detection of polycyclic aromatic hydrocarbons in the plasma of photocopier operators as shown in this study is unexpected and may be due to the method of analysis used, length of exposure or other confounding variables. Thus, further work may be done using more specific method of PAH analysis. It is painful to know that despite the awareness (46\%) of the potential hazards of photocopiers; most of the operators $(66.7 \%)$ were not using any protective device. This observation calls for a quick health education and intervention tailored to monitoring and guiding photocopier operators so as to avoid continuous exposure to the hazards of photocopying machines.

\section{REFERENCES}

1. Krishna CR, Klein CR, Jones KW, Clesceri NL, Stern EA. Human Exposure to Toxic Materials. The Mt Sinai J of Med. 1995; 62: 5

2. Somorvska M, Jahnov E, Tulinska . Biomonitoring of genotoxic risks in workers in a rubber factory in comparison of comet assay with cytogenetic 
method and immunology. Mutat Resp. 1999; 445: 181-192

3. Lebally P, Vigreus C, Lechevrel C, Ledemenev C, Godard T, Sachel F,Letalaer JY, Henry-Amar M, Goudochon P. DNA damage in mononuclear leukocyte of farmers measured using the alkaline comet assay: Discussion of critical parameters and evaluation of seasonal variations in relation to pesticide exposure. Cancer Epidemiol Biomarker Pre. 1998; 7: 917-927

4. Pitarque M, Vaglenov A, Nosko M, Hirvonen A, Norppa H, Creus A, Marcus R. Evaluation of DNA damage by the comet assay in shoe workers exposed to toluene and other organic solvents. Mutat Resp. 1999; 441, 115-12730

5. Zhou JF, Chen WW, Tong GZ. Ozone emitted during copying process: A potential cause of pathological oxidative stress and potential oxidative damage in the bodies of operators. Biomed Environ Sci. 2003; 16 95-104

6. Igbeneghu BI. A Survey of photocopying practices in some selected universities in Western Nigeria. Ozean J of Soc Sci. 2009; 1943-2577

7. Gadhia, P, Patel, D., Solanki, K., Tamakuwala, D. and Pithawala, M. A preliminary cytogenetic and haematological study of photocopying machine operators. Ind J Occup Environ Med. 2005; 9: 22 25

8. Vernier P, Tecchio G, Clonfero E, Levis AG. Mutagenic activity of carbon black dyes used in the leather industry. Mutagenesis. 1987; 2: 19, 22

9. Rosenkranz HS, Mccoy EC, Sanders DR, Butles M, Kirnadez DK, Mermelestein R. Nitropyrenes isolation, identification and reduction of mutagenic impurities in carbon black and toners. Science 1980; 209 :1039-1042

10. Selway MD., Allen RJ, Wadden RA. Ozone production from photocopying machines. Ann. Ind. Hyg Assoc. 1980; 41: 455-459.

11. Lo“froth G, Hefner E, Alfheim I, Moller M. Mutagenic activity in photocopiers. Science 1980; 209:1037-39.

12. Tuomi B, Engstrom R, Niemela J, Svinhufvud K, Reijula. Emission of ozone and organic volatiles from a selection of laser printers and photocopiers. Appl. Occup. Environ. Hyg. 2000; 15: 629-634.

13. Kubika R, Belowskia J, Szczeklika J, Smolikb E, Mielzynskab D, Baja M. Biomarkers of carcinogenesis in humans exposed to polycyclic aromatic hydrocarbons. Mutat Res; 1999; 445:17580

14. Vodikaa P, Tvrdikb T, Osterman-Golkarc S, Vodikovad L, Peterkovaa K, Souekd P. An evaluation of styrene genotoxicity using several biomarkers in a 3-years follow up study of hand lamination workers. Mutat Res 1999; 445; 205-24

15. Lo"froth G, Hefner E, Alfheim I, Moller M. Mutagenic activity in photocopiers. Science 1980; 209, 1037-39.

16. Goud I, Shankarappa K, Vijayashee B, Prabhakar Rao K, Ahuja YR. DNA damage and repair studies in individuals working with photocopying machines. Ind J Hum Genet 2001; 1:129-33

17. Manikantan P, Balachandar V, Sasikala V, Mohanadevi S, Lakshmankumar B. DNA damage in workers occupationally exposed to photocopying machines in Coimbatore South India, using comet assay. The Internet Journal of Toxicology. 2010; 7: 2

18. Bar-Sela S, Shoenfeld Y. Photocopy Machines and Occupational Antiphospholipid Syndrome. IMAJ. 2008; 10:52-54

19. Beers RF, Seizer IW. A spectrophotometric method for measuring breakdown of hydrogen peroxide by catalase. J of Biol Chem, 1952; 195, 133

20. Buege JA, Aust SD. Microsomal lipid peroxidation. Methods Enzymol 1978; 52: 3023106.

21. Soon YY, Tan BKH. Evaluation of the hypoglycemic and antioxidant activities of Morinda officinalis in streptozocin-induced diabetic rats. Singapore Med J. 2002; 43, 077-085

22. Ebuehi OAT, Ajuluchukwu AE, Afolabi OT, Ebuehi OM, Akinwande AI. Catalase activity, lipid peroxidation, Cholesterol and Triglyceride levels in Alloxan induced Diabetes Mellitus in Female and Male rats. Nig. Qt. J. Hosp. Med. 2009; 19, 15-19

23. Valko M, Leibfrithd Moncol J, Crown M, Manzur M, Talser J. Free radicals and antioxidants in normal physiological function and human disease. Int J Biochem Cell Biol. 2007; 39(1). 44-8815.

24. Ho YS, Xiong Y, Ma W, Spector A, Ho D. Mice lacking catalase develop normally but show differential sensitivity to oxidant tissue injury. $J$ Biol Chem. 2004; 279 (31): 32804-812.

25. Chelikani P, Fita I, Loewen PC. Diversity of structures and properties among catalases. Cell. Mol. Life Sci. 2004; 61 (2): 192-208.

26. Anderson ME. Glutathione and glutathione delivery compounds. Adv Pharmacol. 1997; 38:65-78.

27. Li Y, Huang TT, Carlson EJ, Melov S, Ursell PC, Olson JL, Noble LJ, Yoshimura MP, Berger C, Chan PH, Wallace DC, Epstein CJ. "Dilated cardiomyopathy and neonatal lethality in mutant mice lacking manganese superoxide dismutase". Nat. Genet. 1995; 11 (4): 376-81 
28. Kugiyama K, Ohgushi M, Motoyama T. Intracoronary infusion of reduced glutathione improves endothelial vasomotor response to acetylcholine in human coronary circulation. Circulation. 1998; 97:2299-2301.

29. Finkel T, Holbrook NJ. Oxidants, oxidative stress and the biology of aging". Nature 2000; 408 (6809): 239-49

30. Imlay JA. Pathways of oxidative damage. Ann Rev Microbiol. 2003; 57, 395-41839.

31. Seguí J, Gironella M, Sans M, Granell S, Gil F, Gimeno M, Coronel P, Piqué JM, Panés J. Superoxide dismutase ameliorates TNBS-induced colitis by reducing oxidative stress, adhesion molecule expression, and leukocyte recruitment into the inflamed intestine. J. Leukoc. Biol. 2004; 76 (3): 537-44

32. Elchuri S, Oberley TD, Qi W, Eisenstein RS, Jackson Roberts L, Van Remmen H, Epstein CJ, Huang TT. "CuZnSOD deficiency leads to persistent and widespread oxidative damage and hepatocarcinogenesis later in life". Oncogene 2005; 24 (3): 367-80.

33. László Góth. Blood catalase deficiency and diabetes in Hungary. Diabetes Care 2008; 24 (10): e93. 